\title{
Circulation on the shelf and the upper slope of the Bay of Biscay
}

\author{
Arnaud Le Boyer ${ }^{\mathrm{a}, *}$, Guillaume Charria ${ }^{\mathrm{a}}$, Bernard Le Cann ${ }^{\mathrm{b}}$, Pascal Lazure ${ }^{\mathrm{a}}$, Louis Mariéc
}

${ }^{a}$ DYNECO-Physed, Ifremer, Centre de Bretagne, BP 70, 29280 Plouzané, France

b Laboratoire de Physique des Océans, UMR6523 UBO-CNRS-IRD-IFREMER, Université de Bretagne Occidentale, 6, Avenue Le Gorgeu, Brest, 29238 France

c Laboratoire de Physique des Océans, UMR6523 UBO-CNRS-IRD-IFREMER, Ifremer, Centre de Bretagne, BP70, 29280 Plouzané, France

*: Corresponding author : Arnaud Le Boyer, tel.: +33298224330 ; email address : arnaud.leboyer@ifremer.fr

\begin{abstract}
:
Here, we used measurements taken with an array of 10 acoustic Doppler current profilers deployed from July 2009 to August 2011 to describe the tidally filtered circulation over the shelf and upper slope on the French side off the French coasts of the Bay of Biscay. The measurements provided an overview of the shelf and slope circulation throughout the entire water column over a large range of spatial and time scales. The average circulation over the shelf and upper slope of the Bay of Biscay was poleward following the topography with a speed of the order of $3 \mathrm{~cm} \mathrm{~s}^{-1}$. This average circulation had marked seasonal variability. In summer, the currents were equatorward on the outer shelf near surface. Deeper in the water column, the flow remained poleward. In winter, the intensity of the current increased in the north, while it reached its maximum in the south in autumn. On a weekly scale, this behaviour was associated with strong surface currents near the coast in the northern part of the domain in winter and strong currents affected the whole water column in the southern part of the domain in autumn. Correlations of the along-shore currents with wind suggest that wind stress drives almost half of the total observed circulation. We suggest that this forcing acts either directly via local winds or potentially by coastaltrapped waves generated by non-local winds. The potential remote forcing mechanism acts predominately in the southern Bay of Biscay when the wind blows eastward along the northern Spanish coast.
\end{abstract}

\section{Highlights}

Two years time series of the current in the water column from Penmarc'h to Capbreton. Strong surface current near Penmarc'h in winter. Barotropic strong currents close to Capbreton canyon for the autumn. A part of the variability close to the Capbreton canyon is remotely forced.

Keywords: Bay of Biscay ; Observation ; Shelf and slope circulation ; Vertical profile ; ADCP ; Wind driven circulation

\section{Introduction}

The continental shelf of the Bay of Biscay $(\mathrm{BoB})$ west of France is located in the eastern part of the Atlantic Ocean between Capbreton Canyon and Penmarc'h Point (Fig. 1). One feature of the BoB is the northward widening of the shelf. From the Spanish coast to Penmarc'h Point, the width of the continental shelf varies from $60 \mathrm{~km}$ to $\sim 160 \mathrm{~km}$ in front of the Loire River. This study focuses on the circulation on the shelf and the upper part of the continental slope. The continental slope is irregular and has many promontories and canyons (Fig. 1). The first large-scale studies of the area were hydrological (e.g. Vincent and Kurc, 1969a; Le Cann, 1982, Le Cann, 1988 and Puillat et al., 2004). They show a seasonal (from spring to autumn) bottom-trapped water mass with a temperature of $12{ }^{\circ} \mathrm{C}$ between the $60 \mathrm{~m}$ and $120 \mathrm{~m}$ isobaths. This so-called "bourrelet froid" (cold pool) appears after the seasonal thermocline sets up, insulating the bottom water 
Such a pattern can also be observed in other regions like the Irish sea (Brown et al., 2003) and over the Mid-Atlantic Bight (Houghton et al., 1982). The surface temperatures vary from $10^{\circ} \mathrm{C}$ in the north in winter to $>21^{\circ} \mathrm{C}$ in the south in summer. With the exception of winter, the thermocline depth is close to the depth of the $12{ }^{\circ} \mathrm{C}$ isotherm at $\sim 40$ meters depth in spring and $\sim 70$ meters depth in autumn. In winter, the water masses are homogeneous on the vertical.

Despite its complex topography, this area features a classical eastern boundary current system exhibiting a poleward flow on the shelf and slope (Koutsikopoulos and Le Cann, 1996) and is influenced by the eastern edge of the large scale oceanic basin circulation (Pollard and $\mathrm{Pu}, 1985$ ). These open ocean boundary conditions force the slope current to be unstable and generate eddies observed in the interior of the BoB. In addition, they can act in concert with the wind and the buoyancy gradient to drive shelf circulation.

The complex circulation of the BoB has been studied for several years with in situ data. Over the abyssal plain, the average circulation shows a very weak (1-2 $\left.\mathrm{cm} \mathrm{s}^{-1}\right)$ anticyclonic trend (Pingree, 1993). However, the circulation is affected by mesoscale dynamics. Anticyclonic eddies called SWODDies (Pingree and Le Cann, 1992) are generated on the slope of the BoB. The $\star$ generation of these eddies influences the circulation of the open and coastal ocean. The slope current was documented by Pingree and Le Cann (1990) who used available current meter data to establish its flow at a mean speed of $5-10 \mathrm{~cm} \mathrm{~s}^{-1}$. This current is highly seasonal and geographically influenced. Van Aken (2002) and Charria et al. (2011) provide a first overview of the BoBs circulation by analysing the surface circulation $(\sim 15$ to 80 meters 
depth) observed from drifters over the last 17 years. The amount of drifter $\star$ data allows an accurate description of the surface circulation. It shows mean poleward circulation on the slope and a strong seasonal variability on the shelf. For spring and summer, the surface circulation, on the French side of the BoB Shelf and Slope (hereafter, BoBSS), is equatorward while in winter and autumn, at the surface, water masses flow poleward. The circulation in the $\mathrm{BoB}$ is strongly influenced by the seasonal variation of wind (Pingree and Le Cann, 1989), heat fluxes (Somavilla et al., 2012) and freshwater inflow (Lazure and Jegou, 1998; Lazure et al., 2008; Ferrer et al., 2009).

To improve our knowledge of the circulation in the BoBSS, the objective of the ASPEX experiment was to observe the shelf and upper continental slope circulation through the water column over large spatial and temporal ranges. This study focuses on the seasonal dynamics and the horizontal velocities observed over 2 years from July 2009 to August 2011. In section 2 , we describe the scientific project which provides the current data and the numerical model which we use to discuss the wind driven circulation. In section 3, we present a seasonal analysis of the wind regime and the observed circulation in the BoB using different time scales. Then, we discuss in section 4 the influence of the wind on the observed circulation in the BoB and other mechanisms which also drive the circulation. We conclude our work in section 5. 


\section{Data and Methods}

\subsection{ASPEX Experiment}

During the ASPEX project, ten current-meter moorings are deployed over the shelf and the upper part of the slope of the BoB from July 2009 to August 2011. They are organized in three sections (see Figure 1). Moorings 1, 2, 3 constitute the "Penmarc'h section". Moorings 4, 5, 6 compose the "Loire section". The last section along $44^{\circ} \mathrm{N}$, north of the Capbreton canyon is called the " $44^{\circ} \mathrm{N}$ section" with moorings 7, 8, 9 and 10. Each section is instrumented along 3 isobaths with RDI WorkHorse Acoustic Doppler Currents Profilers (ADCP): $~ 450 \mathrm{~m}$ isobath (moorings 3, 6, 10) with ADCP operating at $75 \mathrm{kHz}, \sim 130 \mathrm{~m}$ isobath (mooring 2, 5, 9) with ADCP operating at $150 \mathrm{kHz}$ and the $\sim 60 \mathrm{~m}$ isobath (moorings 1, 4, 7) with ADCP operating at $300 \mathrm{kHz}$. Mooring 8 is an ADCP operating at $300 \mathrm{kHz}$ but it is deployed on the $70 \mathrm{~m}$ isobath. It needs to be noted that the ADCPs are not deployed exactly on the $450 \mathrm{~m}, 130 \mathrm{~m}, 70 \mathrm{~m}$ and $60 \mathrm{~m}$ isobaths but for the sake of simplicity, we use these isobaths for the description of the results and the discussion. The moorings are all swivel- mounted on a frame together with an SBE37 Microcat T/S/P recorder. One difficulty concerning the organization of experiments in this area is the dense fishing activity which can lead to ADCP damage. Special care was taken to detect irregularities in the pressure time series during the recording associated with trawl contact. These error sources were removed from the data and linearly fitted to fill the gaps in the time series. Figure 2 presents the recording time for each mooring after removing the outlier data. We can see that missing data are located mainly in the Loire section at the $130 \mathrm{~m}$ isobath (mooring 5) and in 

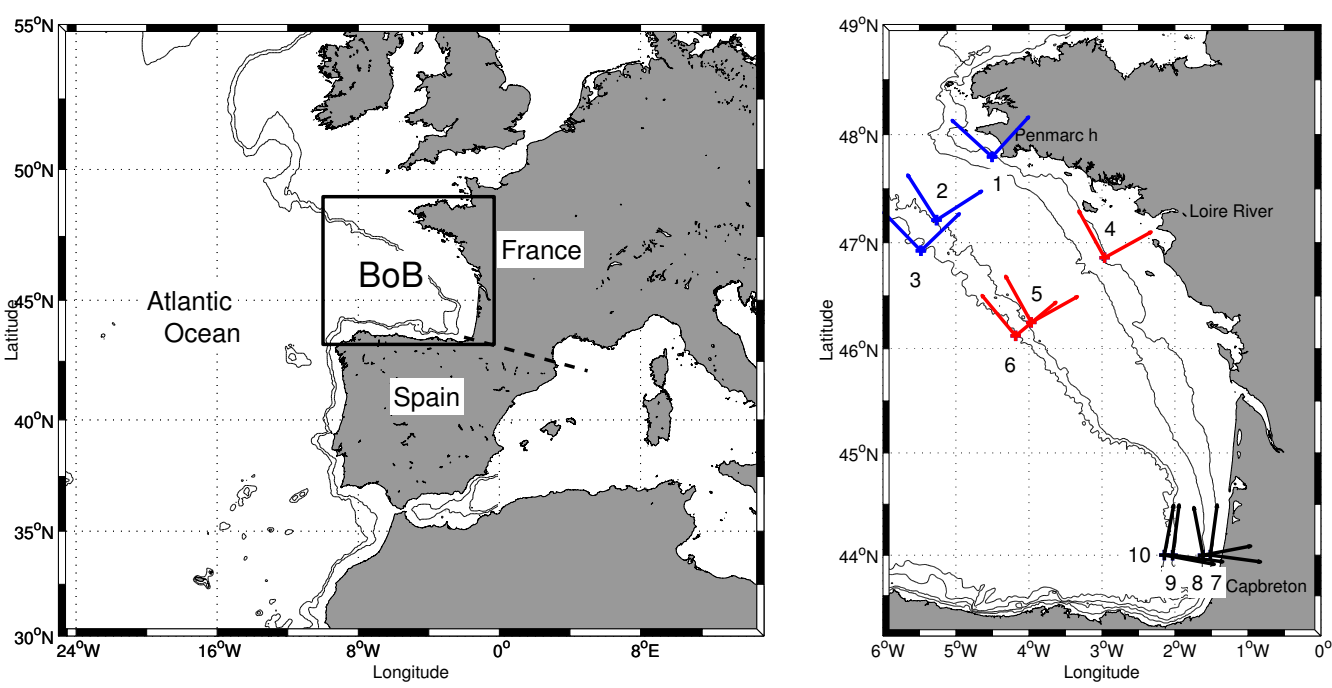

Figure 1: a):Bay of Biscay (BoB) geographical location in the North Atlantic Ocean. b) Mooring positions in the ASPEX project. The numbers are the ASPEX moorings nomenclature. Blue: Penmarc'h section . Red: Loire Section . Black : $44^{\circ} \mathrm{N}$ section. Thin black lines show 60, 100, 130 and $450 \mathrm{~m}$ isobaths. The vectors denote the alongshore and cross-shore directions obtained using the Empirical Orthogonal Function method (see text)

the $44^{\circ} \mathrm{N}$ section at the $70 \mathrm{~m}$ isobath (mooring 8 ). 


\begin{tabular}{|c|c|c|c|c|c|c|c|}
\hline & & \multicolumn{3}{|c|}{ Penmarc'h } & \multicolumn{3}{|c|}{ Loire } \\
\hline & Mooring Number & 1 & 2 & 3 & 4 & 5 & 6 \\
\hline & Latitude $(\mathrm{N})$ & $47^{\circ} 48^{\prime}$ & $47^{\circ} 13^{\prime}$ & $46^{\circ} 55^{\prime}$ & $46^{\circ} 52^{\prime}$ & $46^{\circ} 15^{\prime}$ & $46^{\circ} 07^{\prime}$ \\
\hline & Longitude (W) & $-4^{\circ} 30^{\prime}$ & $-5^{\circ} 16^{\prime}$ & $-5^{\circ} 29^{\prime}$ & $-2^{\circ} 58^{\prime}$ & $-3^{\circ} 58^{\prime}$ & $-4^{\circ} 11^{\prime}$ \\
\hline & Cell size $(\mathbf{m})$ & 2 & 8 & 16 & 2 & 8 & 16 \\
\hline & Sound Frequency $(\mathrm{kHz})$ & 300 & 150 & 75 & 300 & 150 & 75 \\
\hline & Sampling Period (s) & 30 & 30 & 150 & 30 & 30 & 150 \\
\hline \multirow{4}{*}{20092010} & Mooring Depth (m) & 71 & 130 & 453 & 52 & 135 & 423 \\
\hline & Start & $2009 / 07 / 13$ & $2009 / 07 / 13$ & $2009 / 07 / 14$ & $2009 / 07 / 15$ & $2009 / 07 / 16$ & $2009 / 07 / 16$ \\
\hline & End & $2010 / 05 / 13$ & $2010 / 05 / 14$ & $2010 / 05 / 14$ & $2010 / 06 / 29$ & $2009 / 12 / 16$ & $2010 / 05 / 18$ \\
\hline & Duration (days) & 303 & 304 & 304 & 349 & 152 & 306 \\
\hline \multirow{4}{*}{20102011} & Mooring Depth (m) & 71 & 138 & 457 & 47 & 135 & 416 \\
\hline & Start & 2010/08/31 & $2011 / 02 / 02$ & $2010 / 09 / 01$ & $2010 / 09 / 02$ & $2010 / 09 / 03$ & 2010/09/03 \\
\hline & End & 2011/08/07 & $2011 / 06 / 25$ & 2011/08/08 & 2011/08/09 & 2011/01/06 & $2011 / 08 / 13$ \\
\hline & Duration (days) & 341 & 143 & 341 & 341 & 125 & 344 \\
\hline & & \multicolumn{4}{|c|}{$44^{\circ} \mathrm{N}$} & & \\
\hline & Mooring Number & 7 & 8 & 9 & 10 & & \\
\hline & Latitude (N) & $44^{\circ} 00^{\prime}$ & $44^{\circ} 00^{\prime}$ & $44^{\circ} 00^{\prime}$ & $44^{\circ} 00^{\prime}$ & & \\
\hline & Longitude (W) & $-1^{\circ} 31^{\prime}$ & $-1^{\circ} 34^{\prime}$ & $-2^{\circ} 02^{\prime}$ & $-2^{\circ} 09^{\prime}$ & & \\
\hline & Cell size $(\mathbf{m})$ & 2 & 2 & 8 & 16 & & \\
\hline & Sound Frequency $(\mathrm{kHz})$ & 300 & 300 & 150 & 75 & & \\
\hline & Sampling Period (s) & 30 & 30 & 30 & 150 & & \\
\hline \multirow{4}{*}{20092010} & Mooring Depth (m) & 54 & 71 & 138 & 456 & & \\
\hline & Start & 2009/07/19 & $2009 / 07 / 19$ & $2009 / 07 / 18$ & $2009 / 07 / 18$ & & \\
\hline & End & $2010 / 06 / 29$ & $2009 / 10 / 31$ & $2010 / 07 / 01$ & $2010 / 03 / 29$ & & \\
\hline & Duration (days) & 327 & 104 & 347 & 253 & & \\
\hline \multirow{4}{*}{20102011} & Mooring Depth (m) & 54 & 71 & 134 & 454 & & \\
\hline & Start & $2010 / 09 / 05$ & $2011 / 02 / 06$ & $2010 / 09 / 04$ & $2010 / 09 / 05$ & & \\
\hline & End & $2011 / 08 / 10$ & $2011 / 08 / 10$ & $2011 / 07 / 11$ & $2011 / 08 / 10$ & & \\
\hline & Duration (days) & 338 & 184 & 309 & 339 & & \\
\hline
\end{tabular}

Table 1: ASPEX Moorings characteristics 
Table 1 presents the characteristics of the recorded data from the 10 ADCPs located on the shelf and the upper part of the slope of the BoB for the year 2009/2010 and the year 2010/2011. The mooring depth represents the time average of the pressure recorded by the instruments converted to meters. Depending on the instrumented isobath, the cell size of the observations is 2 meters, 8 meters and 16 meters for the 60, 130 and $450 \mathrm{~m}$ isobaths, respectively. The deepest cell which records the current is located above the ADCP at a height of about one and a half cell size. The ADCP beam angle is $20^{\circ}$ to the vertical. Due to the beam angle, the reflection of sound at the surface contaminates cells close to the surface. Thus, only $\sim 80 \%$ (from the deepest cell to the shallowest cell) of the total water column can be sampled. The sampling period is $30 \mathrm{~s}$ for both the $300 \mathrm{kHz}$ and $150 \mathrm{kHz}$ ADCPs and $150 \mathrm{~s}$ for the $75 \mathrm{kHz}$ ADCPs. The collected data are then averaged over 20 min periods. Our study will focus on the tidally filtered time series of these currents. To performed the tide filtering, we used the Godin's tide filter (Godin, 1972). The cut-off period of the Godin's filter is 3.9 days.

The tidally filtered currents were projected into separate along-shore and cross-shore components. Based on the hypothesis that the current variability is strongly constrained by the topography, the along (cross) shore direction is defined by the direction which maximizes (minimizes) the current variability. Applying an Empirical Orthogonal function (EOF) method (Björnsson and Venegas, 1997) to the zonal and meridional components of the vertically averaged and tidally-filtered currents, we obtain two EOF modes on which the current variability can be projected. The eigenvector associated with the first (second) mode maximizes (minimizes) this variability and defines the 


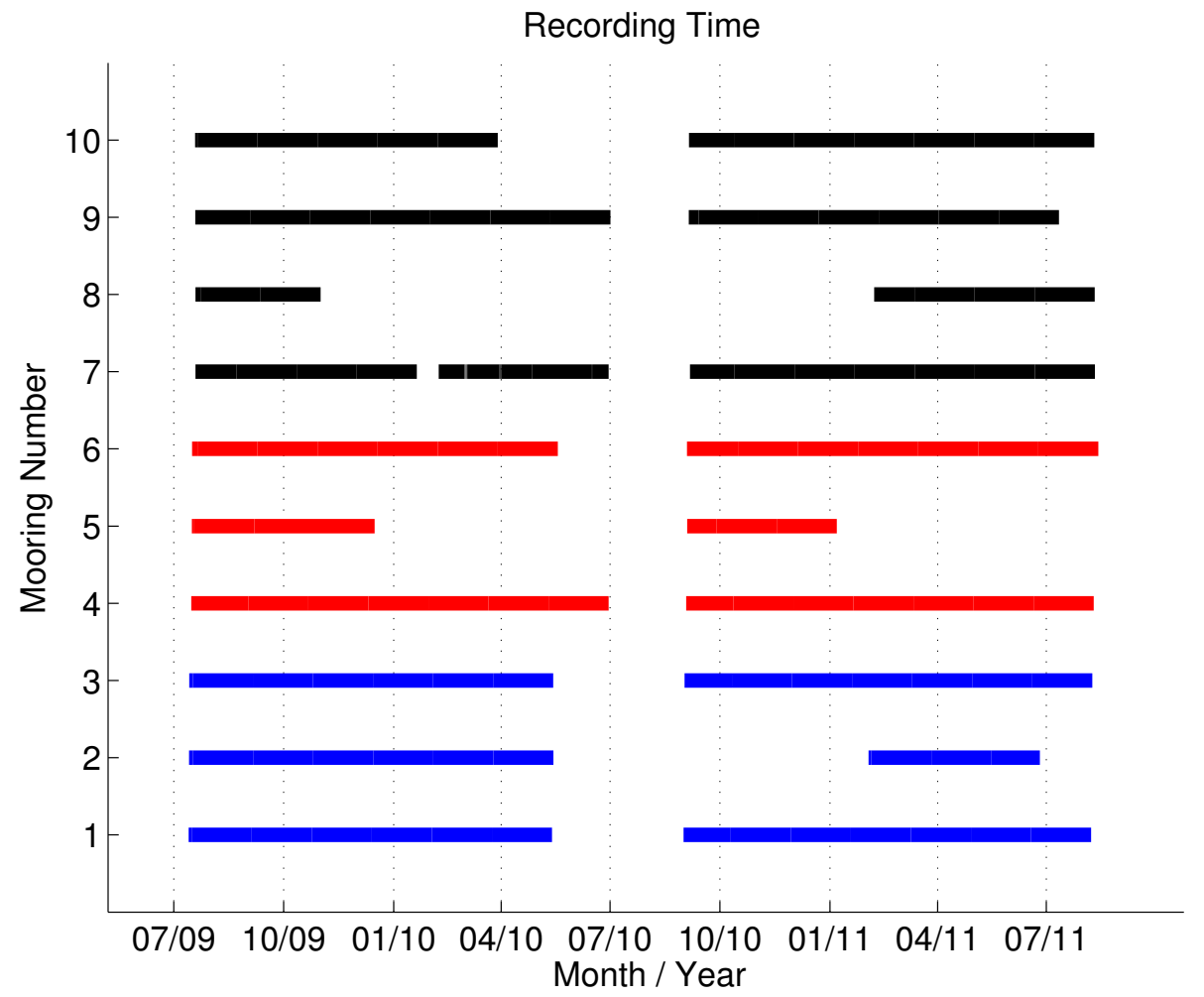

Figure 2: Length of the time record for each mooring after removing outlier data. The colors blue, red and black represent the Penmarc'h, Loire and $44^{\circ} \mathrm{N}$ sections 
along (cross) shore direction. Figure 1 presents the cross-shore and alongshore directions defined by the EOF method. These directions are defined as poleward positive for the along-shore component and positive toward the coast for the cross-shore component.

\subsection{Current processing for seasonal circulation}

Based on the available collected data, we process the dataset to define the seasonal currents. These currents are averaged over three month periods: January, February, March for winter; April, May, June for spring; July, August, September for summer and October, November, December for autumn. We only consider continuous time series longer than a month to define a seasonal time average. This month must be common to at least two moorings along each section to be taken into account. This processing allows a consistent analysis of the seasonal circulation along a section. Table 2 describes the seasonal time series per section for each available season. From summer 2009 to summer 2011, the shortest and the longest seasonal time series are about 34 days and 91 days, respectively. During the two years of measurements, the four seasons were each sampled twice. Summer 2010 is missing because during this season the instruments were retrieved and re-deployed. Thus, the associated time series are too short to be significant. Only summer 2009 and summer 2011 are analysed.

\subsection{ARPEGE Winds}

To understand the dynamics of the $\mathrm{BoB}$ circulation, we compare the ASPEX data to the winds in the BoB over the two years of measurements. The winds are from the ARPEGE atmospheric general circulation model 


\begin{tabular}{|c|c|c|c|c|}
\hline & & Penmarch & Loire & $44^{\circ}$ \\
\hline \multirow{4}{*}{ Summer 2009} & Start Date & $07 / 16 / 2009$ & $07 / 19 / 2009$ & $07 / 22 / 2009$ \\
\hline & End Date & $09 / 30 / 2009$ & 09/30/2009 & 09/30/2009 \\
\hline & Length (days) & 76 & 73 & 70 \\
\hline & Mooring Id & 123 & 456 & 78910 \\
\hline \multirow{4}{*}{ Autumn 2009} & Start Date & $10 / 01 / 2009$ & $10 / 01 / 2009$ & $10 / 01 / 2009$ \\
\hline & End Date & $12 / 31 / 2009$ & $12 / 12 / 2009$ & $12 / 31 / 2009$ \\
\hline & Length (days) & 91 & 72 & 91 \\
\hline & Mooring Id & 123 & 456 & 7910 \\
\hline \multirow{4}{*}{ Winter 2010} & Start Date & $01 / 01 / 2010$ & $01 / 01 / 2010$ & $02 / 10 / 2010$ \\
\hline & End Date & $03 / 31 / 2010$ & $03 / 31 / 2010$ & $03 / 26 / 2010$ \\
\hline & Length (days) & 89 & 89 & 43 \\
\hline & Mooring Id & 123 & 46 & 7910 \\
\hline \multirow{4}{*}{ Spring 2010} & Start Date & $04 / 01 / 2010$ & $04 / 01 / 2010$ & $04 / 01 / 2010$ \\
\hline & End Date & $05 / 10 / 2010$ & $05 / 15 / 2010$ & 06/26/2010 \\
\hline & Length (days) & 39 & 44 & 86 \\
\hline & Mooring Id & 123 & 46 & 79 \\
\hline \multirow{4}{*}{ Autumn 2010} & Start Date & $10 / 01 / 2010$ & $10 / 01 / 2010$ & $10 / 01 / 2010$ \\
\hline & End Date & $12 / 31 / 2010$ & $12 / 31 / 2010$ & $12 / 31 / 2010$ \\
\hline & Length (days) & 91 & 91 & 91 \\
\hline & Mooring Id & 13 & 456 & 7910 \\
\hline \multirow{4}{*}{ Winter 2011} & Start Date & $02 / 05 / 2011$ & $01 / 01 / 2011$ & $02 / 09 / 2011$ \\
\hline & End Date & $03 / 31 / 2011$ & $03 / 31 / 2011$ & $03 / 31 / 2011$ \\
\hline & Length (days) & 54 & 89 & 50 \\
\hline & Mooring Id & 123 & 46 & 78910 \\
\hline \multirow{4}{*}{ Spring 2011} & Start Date & $04 / 01 / 2011$ & $04 / 01 / 2011$ & $04 / 01 / 2011$ \\
\hline & End Date & $06 / 22 / 2011$ & $06 / 30 / 2011$ & 06/30/2011 \\
\hline & Length (days) & 82 & 90 & 90 \\
\hline & Mooring Id & 123 & 46 & 78910 \\
\hline \multirow{4}{*}{ Summer 2011} & Start Date & $07 / 01 / 2011$ & $07 / 01 / 2011$ & $07 / 01 / 2011$ \\
\hline & End Date & 08/04/2011 & 08/06/2011 & 08/07/2011 \\
\hline & Length (days) & 34 & 36 & 37 \\
\hline & Mooring Id & 13 & 46 & 7810 \\
\hline
\end{tabular}

Table 2: Seasonal Time series characteristics per season and per section. Note that there is no data for summer 2010 . 
(GCM) from Météo-France (Déqué et al., 1994). The model outputs are sampled every 6 hours and its spatial grid has a $0.5^{\circ}$ resolution. We use the ARPEGE winds within a range from $43.5^{\circ} \mathrm{N}$ to $48.5^{\circ} \mathrm{N}$ and from $1^{\circ} \mathrm{W}$ to $7^{\circ} \mathrm{W}$

\subsection{Time-lagged Wind-Current correlations}

In section 3.5, the wind driven circulation is estimated based on the computation of the time-lagged correlation of the along-shore velocities with the local winds projected on axes varying on angles from 0 to $2 \pi$. We focus on time lags shorter than 7 days in order to discuss about synoptic time scales and shorter periods. The maximum correlation and the corresponding angle allow an estimation of the wind component for which the variations of the along-shore currents and winds are in phase. We also have access to the time lags associated with these maximum values of correlation. This information is a good proxy to estimate the influence of the local winds or other forcing.

\section{Results}

\subsection{Wind Regimes in the Bay of Biscay}

An EOF method implemented on the BoB wind field indicates that the wind field exhibits weaker spatial variation at the scale of the analysis. For the studied period, the first EOF mode explains about $77 \%$ of the total variability and the spatial structure (eigenvector) is uniform. Figure 3a shows the $1^{\text {st }} \mathrm{EOF}$ mode of the winds. It indicates that the wind variations are coherent and similar over the whole BoB.

In figure $3 \mathrm{~b}$, the wind vectors are spatially averaged over the domain adopted for the wind field. We present here, the seasonal evolution of this 
spatial average. The winds in the $\mathrm{BoB}$ are expected to be southeastward in the summer and mainly northeastward in the winter with transition periods of two months between each phase. The transition periods should occur in September/October and March/April. These changes in the wind direction are called the SOMA effect (Pingree, 1999). However, the seasonal wind evolution shows some inter-annual variability. The wind regime in autumn 2009 is strongly northeastward and they southeastward in autumn 2010. This season exhibits a Navidad event Garcia-Soto and Pingree (2012). This event and its influence are discussed in section 4. Furthermore, winter 2010 is strongly northward. This is due to two important storms that occurred this winter. One of them was the Xinthia storm which caused many damages in the west coast of France.

\subsection{Mean circulation}

The observed mean circulation (vertically and time averaged over the available data) from July 2009 to August 2011 (blue arrows in figure 4) is mainly poleward following the topography with currents of order of 3 $\mathrm{cm} \mathrm{s} \mathrm{s}^{-1}$. On the slope, the mean currents tend to increase poleward while the circulation on the shelf presents a less coherent spatial variability. The strongest mean currents $\left(\sim 5 \mathrm{~cm} \mathrm{~s}^{-1}\right)$ are found at the $450 \mathrm{~m}$ isobath in the Penmarc'h section and they decrease over the slope to $2 \mathrm{~cm} \mathrm{~s}^{-1}$ in the Loire section and in the $44^{\circ} \mathrm{N}$ section. The circulation in front of the Loire river is weaker $\left(1 \mathrm{~cm} \mathrm{~s}^{-1}\right)$ and eastward at the $130 \mathrm{~m}$ isobath. In the $44^{\circ} \mathrm{N}$ section, the mean current at the $60 \mathrm{~m}$ isobath is about $4 \mathrm{~cm} \mathrm{~s}^{-1}$. The results at the $70 \mathrm{~m}$ isobath in the $44^{\circ} \mathrm{N}$ section and at the $130 \mathrm{~m}$ isobath in front of the Loire river should be analysed carefully because the associated time series 

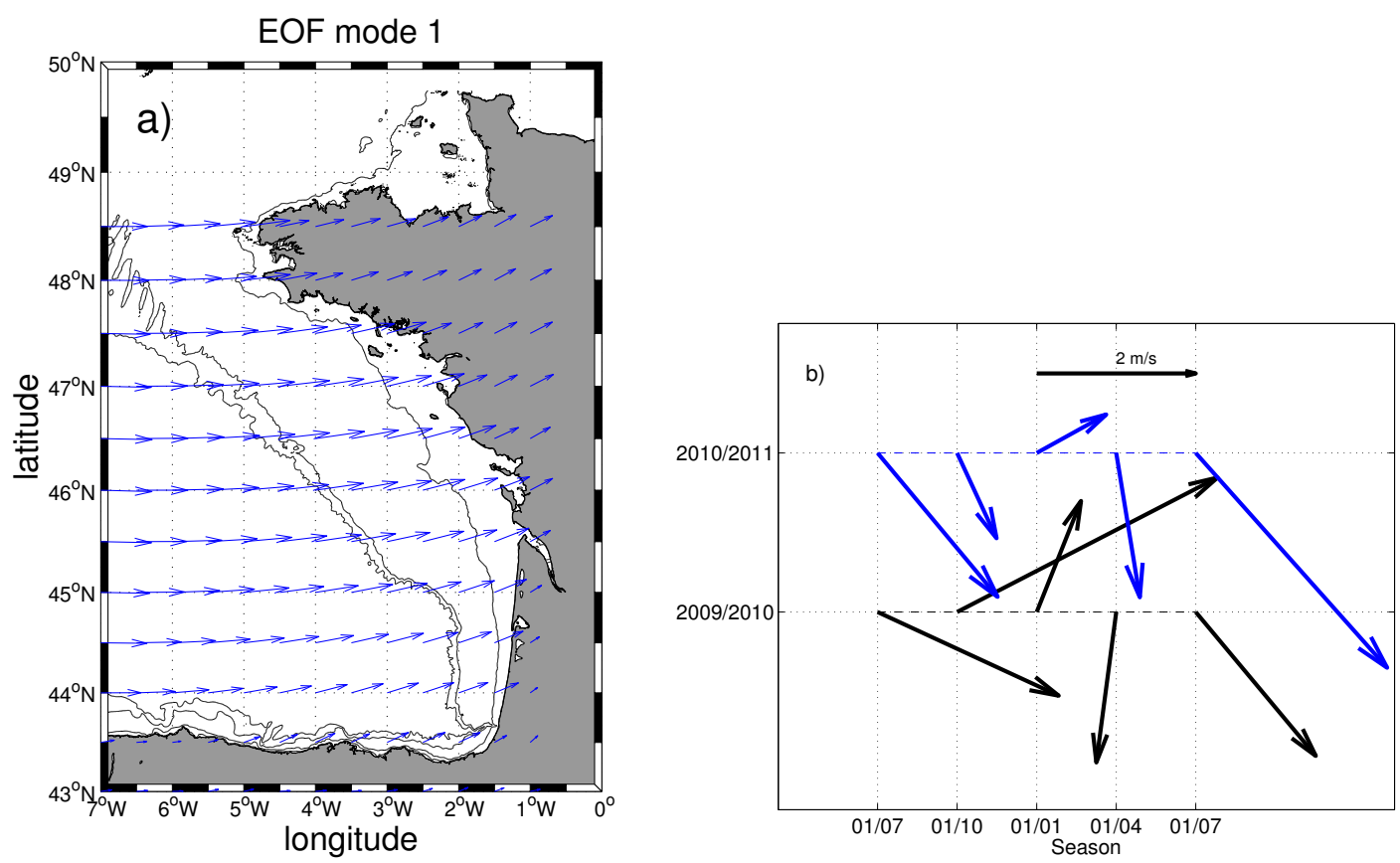

Figure 3: a) Spatial structure of the first EOF mode of the Bay of Biscay's Winds, b) Monthly averaged wind in the Bay of Biscay for the year 2009/2010 (black) and 2010/2011 (blue). 
presents less than 200 days (thin arrows on figure 4) of data compared to more than 600 days of data for most of the others .

These mean currents are compared with the mean winds observed in the middle of each section over the two years of the experiment (red arrows). The wind at these locations presents a good proxy of the wind over the whole section. The mean winds veer southward with decreasing latitudes and the mean currents are poleward following topography. The mean winds are eastward with an intensity of $2 \mathrm{~m} \mathrm{~s}^{-1}$ along the Penmarc'h latitude and turn southward in the southern part of the BoB. Winds are opposed to the currents in most locations.

\subsection{Seasonal circulation}

\subsubsection{Depth-averaged circulation}

The depth averaged seasonal circulation is represented on Figure 5a. Like the mean circulation over the two years, seasonal currents are generally poleward and they flow along the topography.

In autumn, the circulation is poleward over all the BoBSS. Differences appear in the intensity of the circulation. The intensity of the circulation in the northern part of the BoBSS (Penmarc'h and Loire sections) is similar for currents at the 60 and $450 \mathrm{~m}$ isobaths of about $5 \mathrm{~cm} \mathrm{~s}^{-1}$ and weaker currents of about $2 \mathrm{~cm} \mathrm{~s}^{-1}$ at the $130 \mathrm{~m}$ isobath. In the $44^{\circ} \mathrm{N}$ section the weaker $(2$ $\left.\mathrm{cm} \mathrm{s}^{-1}\right)$ currents are near the coast (60 $\mathrm{m}$ isobath). The currents increase off shore with an intensity of about $5 \mathrm{~cm} \mathrm{~s}^{-1}$.

In winter, the currents are poleward along the $60 \mathrm{~m}$ isobath increasing northward with a maximum at Penmarc'h about $5 \mathrm{~cm} \mathrm{~s}^{-1}$. Along the 130 


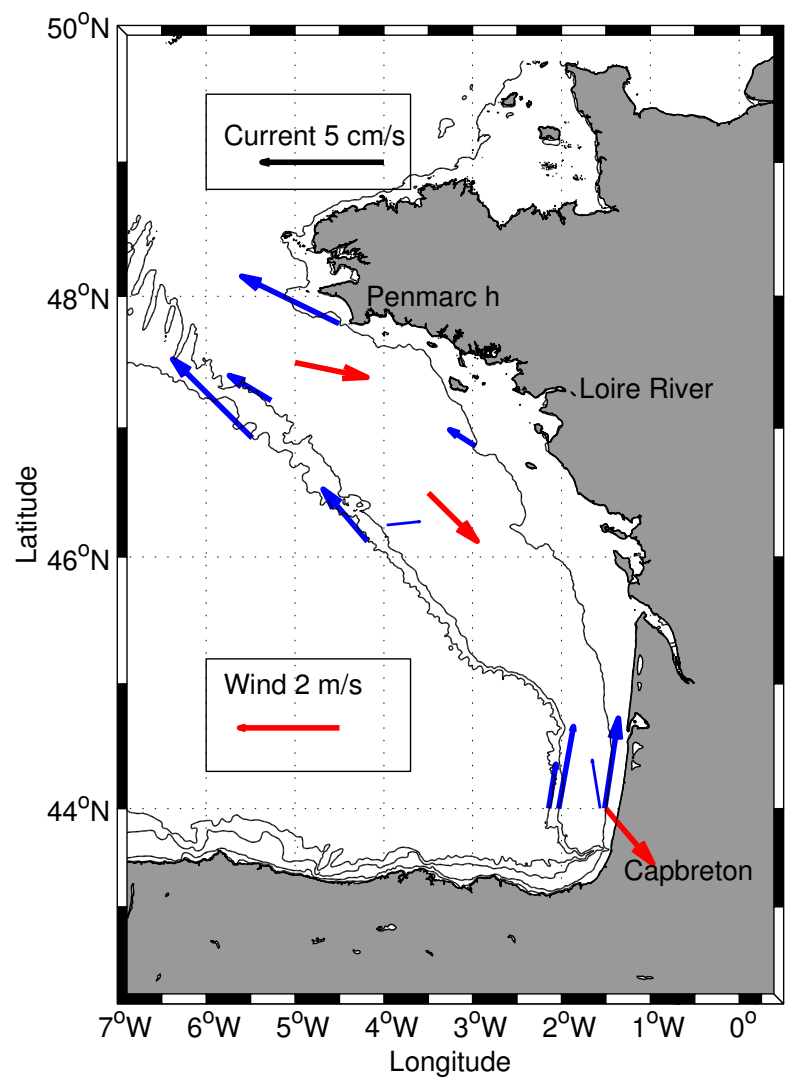

Figure 4: Two years average of the vertically averaged currents (blue arrows) and mean winds (red arrows) for the two years of the experiment. The black lines are the 60, 130 and $450 \mathrm{~m}$ isobaths. The thin arrows indicate data coverage less than 200 days of data 
$\mathrm{m}$ isobath, the winter currents are poleward and about $3 \mathrm{~cm} \mathrm{~s}^{-1}$ in the Penmarc'h and $44^{\circ} \mathrm{N}$ sections. The circulation on the upper slope (450 m isobath) in winter is also poleward increasing southward with a maximum in the $44^{\circ} \mathrm{N}$ section about $5 \mathrm{~cm} \mathrm{~s}^{-1}$.

In spring, the currents are weakly poleward almost everywhere $(\sim 1 \mathrm{~cm}$ $s^{-1}$ ) in the BoBSS. However, two moorings present different behaviors. The spring currents in the Penmarc'h section on the upper part of the slope (450 $\mathrm{m}$ isobath $)$ are strong $\left(5 \mathrm{~cm} \mathrm{~s}^{-1}\right)$ and the currents at the $60 \mathrm{~m}$ isobath in the Loire river section are slightly southward in the same direction as the mean winds over all the area for spring.

The summer circulation is globally weaker than during winter and autumn. The currents in the Penmarc'h section are poleward with a maximum at the $60 \mathrm{~m}$ isobath $\left(5 \mathrm{~cm} \mathrm{~s}^{-1}\right)$ and a minimum at the $130 \mathrm{~m}$ isobath $(\sim 1$ $\mathrm{cm} \mathrm{s}^{-1}$ ). In the Loire section, the currents are eastward on the shelf (60 and $130 \mathrm{~m}$ isobaths ) and poleward on the upper slope (450 $\mathrm{m}$ isobath ). In the $44^{\circ} \mathrm{N}$ section, the currents near the coast (60 m isobath) are poleward and the strongest in the area $\left(5 \mathrm{~cm} \mathrm{~s}^{-1}\right)$. At the 130 and $450 \mathrm{~m}$ isobaths, the currents of the $44^{\circ} \mathrm{N}$ section are equatorward with an amplitude of $\sim 1 \mathrm{~cm}$ $s^{-1}$.

The seasonal variance of the tidally-filtered depth averaged currents is presented in Figure 5b. Similar to the seasonal averages, the current variability is constrained by the topography with larger variances close to the 

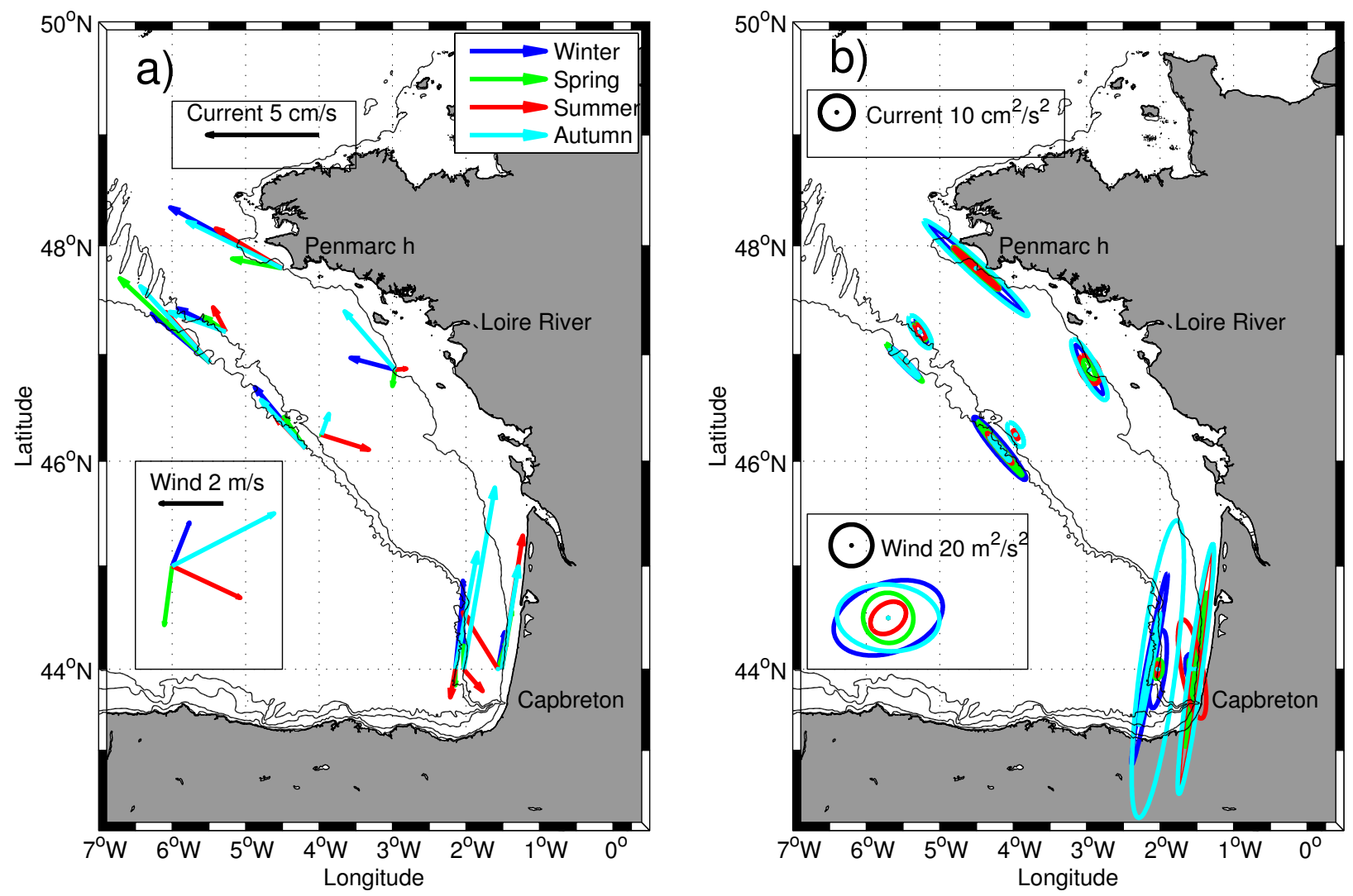

Figure 5: a) Seasonal average of depth averaged currents. Between $45^{\circ} \mathrm{N}-6^{\circ} \mathrm{W}$, seasonal and spatial average of the winds over the domain. Summer season at all locations and spring in the Penmarc'h section present time series of about a month in one of the two sampled seasons. b) Seasonal variability of the depth averaged currents. At $45^{\circ} \mathrm{N}-6^{\circ} \mathrm{W}$, seasonal variability of the averaged winds over the domain. Black lines indicates the 60, 130 and $450 \mathrm{~m}$ isobaths 
coast and on the upper slope. The variance in autumn is the strongest along all sections except in the Loire section on the upper slope (isobath $450 \mathrm{~m}$ ) where the variance reaches its smallest value in autumn $\left(10 \mathrm{~cm}^{2} \mathrm{~s}^{-2}\right)$. Current variance amplitude during this season ranges from $6 \mathrm{~cm}^{2} \mathrm{~s}^{-2}$ over the $130 \mathrm{~m}$ isobath in the Loire section to $100 \mathrm{~cm}^{2} \mathrm{~s}^{-2}$ in the $44^{\circ} \mathrm{N}$ section over the same isobath. In winter, the current variances remain intense with values around $63 \mathrm{~cm}^{2} \mathrm{~s}^{-2}$ on the upper slope in the $44^{\circ} \mathrm{N}$ section or $40 \mathrm{~cm}^{2} \mathrm{~s}^{-2}$ above the $60 \mathrm{~m}$ isobath in the Penmarc'h section. In spring and summer, current variances are weaker. For example, over the $130 \mathrm{~m}$ isobath in the Penmarc'h and $44^{\circ} \mathrm{N}$ sections, variance falls to $6 \mathrm{~cm}^{2} \mathrm{~s}^{-2}$.

\subsubsection{Seasonal vertical current profiles}

Figure 6 presents the seasonal vertical profiles of the along-shore and cross-shore current components for each section. These profiles allow to highlight the different features between the shelf and the slope circulations.

Over the $450 m$ isobath.

On the upper slope (450 $\mathrm{m}$ isobath), vertical profiles of the along-shore current exhibit a poleward circulation except in spring and summer along the $44^{\circ} \mathrm{N}$ section. However, the vertical structure exhibits a spatial and temporal variability. In winter, Loire and $44^{\circ} \mathrm{N}$ sections have an increasing velocity from near bottom depth (almost null velocity) to surface (reaching $10 \mathrm{~cm}$ $\left.s^{-1}\right)$. In autumn and summer along the Penmarc'h and Loire sections, the profile have a maximum speed at around $130 \mathrm{~m}$ depth $\left(\sim 8 \mathrm{~cm} \mathrm{~s}^{-1}\right)$. We observe three groups of profiles:

- linearly increasing speed from depth to surface observed during in autumn 

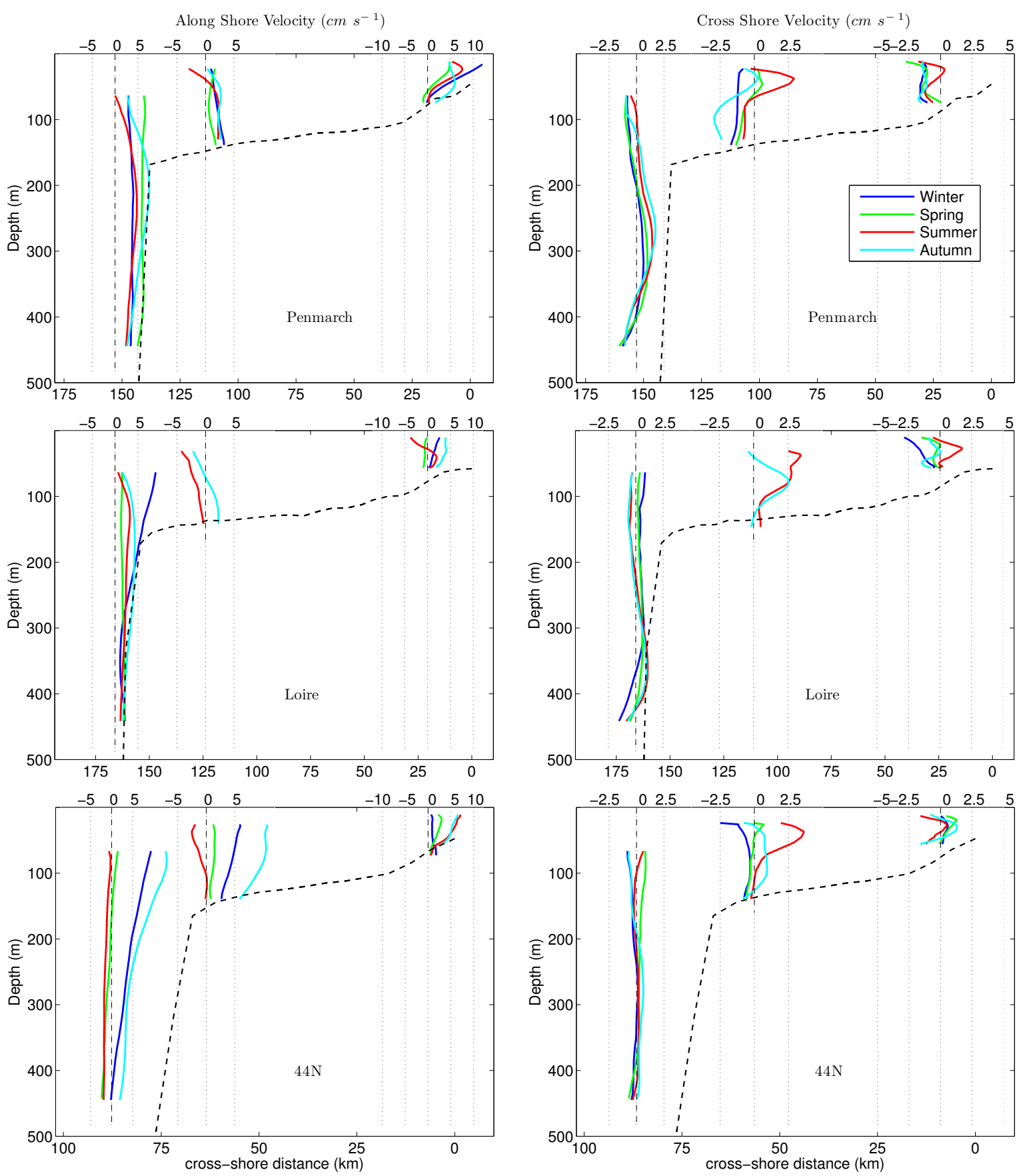

Figure 6: Seasonal vertical profiles of the along-shore (left panels) positive poleward and cross-shore (right panels) positive shoreward components of the currents for Penmarc'h (upper panels), Loire (mid panels) and $44^{\circ} \mathrm{N}$ (bottom panels) sections. Blue lines: winter, Green lines: spring, Red lines: summer and Cyan lines: autumn. X-axis scales of the vertical profile are in $\mathrm{cm} \mathrm{s}^{-1}$ and changes for each isobath. On all these graphs, the position of the profiles have been adjusted for the sake of clarity. 
and winter in the southern part of the BoBSS,

- profiles with a maximum poleward speed around $130 \mathrm{~m}$ depth in spring and summer in the northern part of the BoBSS,

- profiles with equatorward deep velocities and weak currents at surface in spring and summer in the South of the BoBSS.

The vertical profiles of the cross-shore currents are characterized by weaker velocities than in the along-shore direction. The maximum observed crossshore seasonal mean velocity is $\sim 2 \mathrm{~cm} \mathrm{~s}^{-1}$ in the Penmarc'h section in autumn. We observe downslope velocities near the bottom and upslope velocities above 350-400 meter depth with a maximum at 250-350 meter depth. The depth of the current inversion slightly changes with the season. Along the $44^{\circ} \mathrm{N}$ section, the seasonal velocities are weak $\left(1 \mathrm{~cm} \mathrm{~s}^{-1}\right)$ and shows no important vertical shear and no important seasonal variability.

Over the $130 m$ isobath.

From autumn to spring, currents flow mainly poleward except in a surface layer along Loire section (above $70 \mathrm{~m}$ depth). However, the shape of profiles differs between $44^{\circ} \mathrm{N}$ and Penmarc'h sections. Indeed, largest velocities are observed near the surface in the south and near the bottom in the north $\left(\sim 4 \mathrm{~cm} \mathrm{~s}^{-1}\right)$. Another difference between these two sections is that the seasonal variability is strong along the $44^{\circ} \mathrm{N}$ section with maximum speeds in autumn reaching $>10 \mathrm{~cm} \mathrm{~s}^{-1}$. The summer remains the only season when equatorward currents are measured (3 to $5 \mathrm{~cm} \mathrm{~s}^{-1}$ at surface).

Along this isobath, cross-shore currents have amplitudes slightly less than the along-shore current amplitude. In summer, significant upslope currents 
$\left(\sim 2.5 \mathrm{~cm} \mathrm{~s}^{-1}\right)$ are observed. The vertical shear, characterized by a subsurface onshore velocity maximum, is also strong along the Penmarc'h and Loire sections and in summer along the $44^{\circ} \mathrm{N}$ section. On the contrary, in winter, profiles are more vertical and offshore.

Over the $60 \mathrm{~m}$ isobath.

Along the $60 \mathrm{~m}$ isobath , the along-shore currents are mainly poleward reaching $12 \mathrm{~cm} \mathrm{~s}^{-1}$ in the Penmarc'h section in winter at the surface. The mean along-shore velocities are almost null at the bottom and increase toward the surface. Only the summer profile for the Loire section differs from surface equatorward currents with an intensity of $5 \mathrm{~cm} \mathrm{~s}^{-1}$.

The vertical profiles of the cross-shore currents at the $60 \mathrm{~m}$ isobath are coherent with profiles for the $130 \mathrm{~m}$ isobath showing a subsurface maximum trend during spring, summer and autumn. In winter, the vertical profile shape is different. Vertical velocity gradients are weaker suggesting the importance of seasonal stratification for the rest of the year.

\subsection{Weekly circulation}

The amount of energy represented by the variance ellipses and their variability depicted in the previous section (figure 5) led us to observe the results at higher frequencies. The tidally filtered time series of the weekly circulation in the BoBSS at near surface and near bottom depths is presented in figure 7. The weekly averages of the along-shore currents along the 60, 130 and 450 $\mathrm{m}$ isobaths show strong along-shore currents values reaching $30 \mathrm{~cm} \mathrm{~s}^{-1}$ close to the surface at all isobaths. The results for the $130 \mathrm{~m}$ isobath are not presented because they are similar to the times series at the $450 \mathrm{~m}$ isobath with 
strong currents that occurred for autumn at the south of BoBSS (figure 5). Furthermore, at this isobath, the circulation for the two sections (Penmarc'h and Loire) present some gaps in the time series. In the $44^{\circ} \mathrm{N}$ section, the 450 $\mathrm{m}$ isobath present the strongest along-shore currents. In autumn 2009 and autumn 2010, the current intensity reaches $>30 \mathrm{~cm} \mathrm{~s}^{-1}$. These seasonal two events are marked by several monthly episodes of intensified poleward currents. The near bottom cross-shore currents at this location are always downslope and increase during strong poleward currents (not shown). The strongest currents $\left(>20 \mathrm{~cm} \mathrm{~s}^{-1}\right)$ along $60 \mathrm{~m}$ isobath are at Penmarc'h in spring 2010 and 2011 and in the $44^{\circ} \mathrm{N}$ section in autumn 2009 and 2010. At the Penmarc'h section, the currents are surface intensified and at the the $44^{\circ} \mathrm{N}$ section the strong currents are also observed near the bottom. These strong current events occurring in the $44^{\circ} \mathrm{N}$ section, either at the $60 \mathrm{~m}$ isobath or the $450 \mathrm{~m}$ isobath (Blue lines), are followed by a current peak in the Loire section (Black lines). They occurred in autumn $\left(6^{\text {th }}\right.$ November 2009 at the $60 \mathrm{~m}$ isobath and $\sim 15^{\text {th }}$ November 2010 at the $450 \mathrm{~m}$ isobath) or early winter ( $\sim 1^{\text {st }}$ January 2011 at the $450 \mathrm{~m}$ isobath).

The summer and autumn 2009 near bottom circulation recorded at the $44^{\circ} \mathrm{N}$ section at the $60 \mathrm{~m}$ isobath is not correlated with the one at the Penmarc'h section. After the barotropic events occurring at the $44^{\circ} \mathrm{N}$ section, figure 7 shows some coherent variations of about $10 \mathrm{~cm} \mathrm{~s}^{-1}$ for the three sections from January to May 2010 with a period of about a month along the $60 \mathrm{~m}$ isobath. These coherent oscillations seem to cease at the beginning of summer seasons. This specific behaviour also occurs after autumn 2010 and during winter 2011. At the $450 \mathrm{~m}$ isobath, the near bottom circulation 

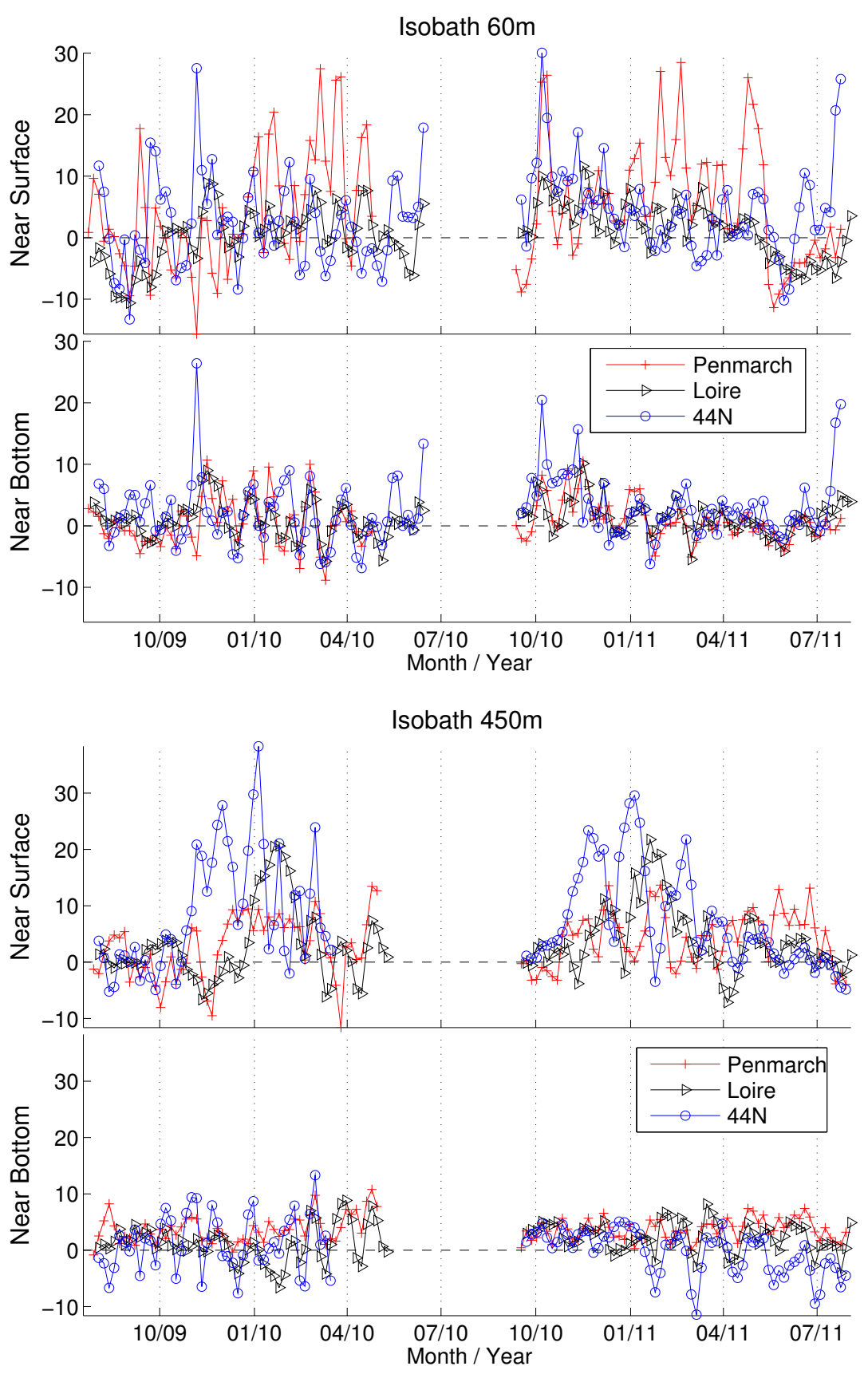

Figure 7: Weekly average of the along-shore velocities in $\mathrm{cm} \mathrm{s} \mathrm{s}^{-1}$ near the bottom depth and near the surface. Upper and lower panels present the velocities at the $60 \mathrm{~m}$ isobath (surface: $7 \mathrm{~m}$ depth and bottom: $53 \mathrm{~m}$ depth) and $450 \mathrm{~m}$ (surface: $53 \mathrm{~m}$ depth and bottom: $378 \mathrm{~m}$ depth), respectively. Red, Black and Blue lines are velocities at moorings along Penmarc'h, Loire and $44^{\circ} \mathrm{N}$ sections respectively. 
also shows behaviour changes according to the seasons. The near bottom currents are in the range of $\pm 5 \mathrm{~cm} \mathrm{~s}^{-1}$ for summer and autumn of both years (2009 and 2010) while they stay in the range of $\pm 10 \mathrm{~cm} \mathrm{~s}^{-1}$ for the rest of the year (winter and spring). Oscillations observed near the bottom such as the ones observed on the $60 \mathrm{~m}$ isobath occurred only in the south of the BoB for late autumn 2009, winter 2010, winter and spring 2011. In the Penmarc'h and Loire sections the variability of the along-shore current along the $450 \mathrm{~m}$ isobath stands within a range of $-1 \mathrm{~cm} \mathrm{~s}^{-1}$ to $10 \mathrm{~cm} \mathrm{~s}^{-1}$. The $450 \mathrm{~m}$ isobath circulations in these sections for stratified seasons (summer and autumn) occurs in the same period of time while for winter and spring, the Loire section currents follow the $44^{\circ} \mathrm{N}$ section current variations.

Coherent flows all over the BoB or over a large part of the area may be the response to large scale forcing. In the section 4 , we discuss the possibility that large scale forcing leads to the circulation in the BoB.

\subsection{Wind Driven Circulation}

A first step toward the understanding of the tidally filtered $\mathrm{BoB}$ circulation is to estimate the wind driven circulation part from the total circulation. Figure 8 presents the maximum values of the time lagged correlations of the depth averaged along-shore velocities and the local along-shore winds stress along the $60 \mathrm{~m}$ isobath. This analysis focus on the seasonal behaviour of the correlations of the wind stress with the depth averaged along-shore currents. The correlations are presented as a function of the direction of the wind component which lead to these values. They stand within a range of $\sim 0.4-0.8$. The correlations of the wind with currents at the $130 \mathrm{~m}$ and $450 \mathrm{~m}$ isobaths fall under 0.5 (not shown). 
The correlations at the $60 \mathrm{~m}$ isobath can be split into two groups. Some points are localized close to the along-shore directions showing that wind in the along-shore direction has maximum effect and the other group of points is localized to the west of these along-shore directions. We see that these two groups may be better characterized as a geographical criterion rather than a seasonal influence. Indeed, the depth-averaged along-shore currents in the Penmarc'h and Loire sections are correlated with winds projected on the local along-shore directions while in the $44^{\circ} \mathrm{N}$ section the along shore currents are well correlated with westerlies. In the Loire section, the highest correlation occurs in spring while autumn winds are well correlated with the depth averaged circulation in the Penmarc'h section. In both sections, correlations slightly decrease in summer. In the $44^{\circ} \mathrm{N}$ section, only the correlation in winter 2010 (blue triangles) is aligned with the local along-shore direction (i.e: north-south). All other seasonal along-shore current / wind correlations at this section are not aligned with the along-shore direction and the associated points are part of the second group of points that we have define. Some other correlation points are not aligned with the local topography in the Penmarc'h section for winter 2010 and Loire section for summer 2009, winter 2010 and autumn 2010. Thus, the correlations are not influenced by the local winds and might be indicative of remote forcing mechanism transmitted by coastal trapped waves.

Figure 9 presents the time lags in days which gives the maximum correlations presented in the figure 8. The maximum correlation is obtained for different time lags from 0 to 3.5 days. The Penmarc'h and Loire sections present either time lags of $\sim 10$ hours or longer time lags from 2.5 to 3.5 


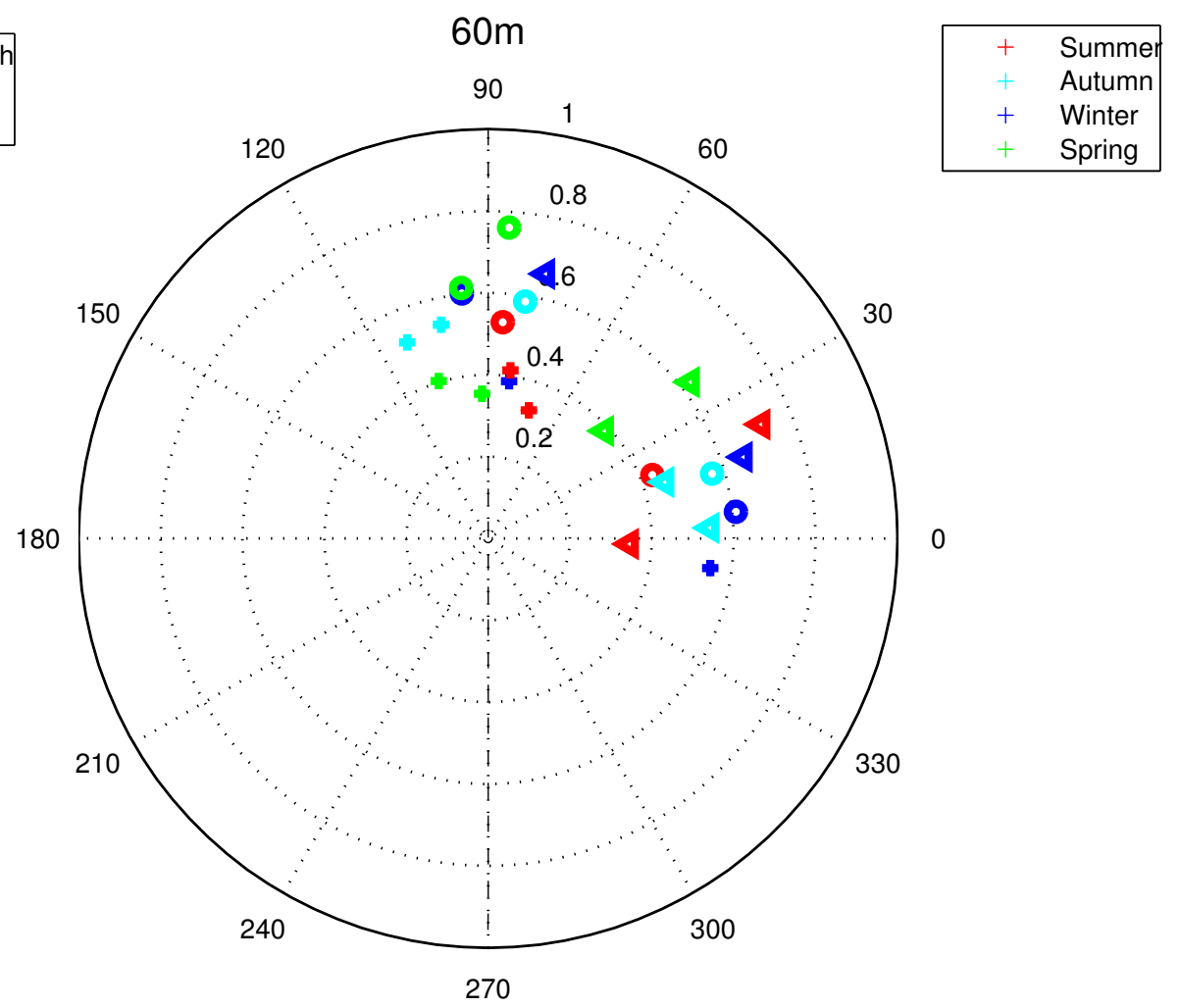

Figure 8: Maximum correlations of the depth averaged along-shore velocities at the $60 \mathrm{~m}$ isobath with the local wind. The radii give the value of the correlation, the azimuths give the wind orientation relative to the poleward along-shore circulation where the maximum correlation is reached. The crosses, circles and triangles are the Penmarc'h, Loire and $44^{\circ} \mathrm{N}$ section's moorings, respectively. The red, cyan, blue and green symbols represent the summer, autumn, winter and spring seasons, respectively. The black dashed lines represents the local along-shore direction of the $60 \mathrm{~m}$ isobath at Penmarc'h, Loire and $44^{\circ} \mathrm{N}$ sections. 


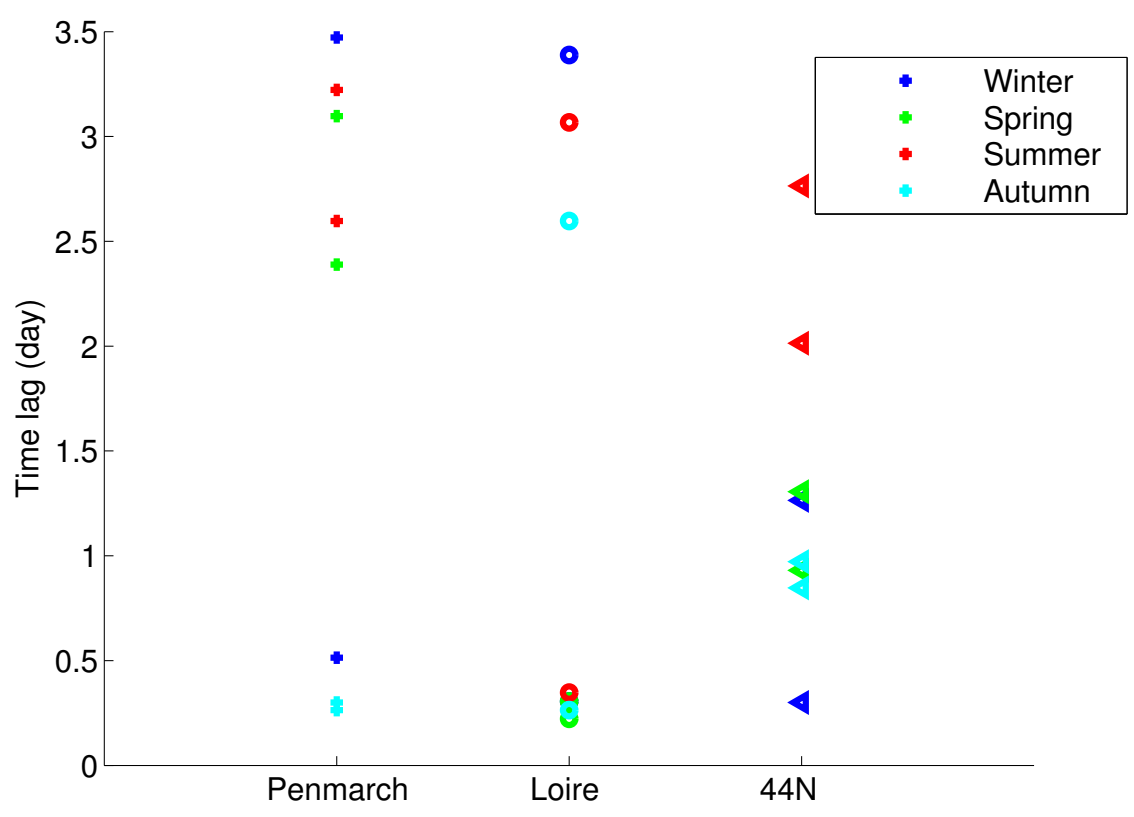

Figure 9: Time lags in days which gives the maximum correlation values presented in the figure 8. The time lags are presented per section and per season: winter in blue, spring in green, summer in red and autumn in cyan. 
days. In the $44^{\circ} \mathrm{N}$ section, the time lags are about 1 day. In the summer season, the time lags increase to 2-3 days and only winter 2010 have time lag of 10 hours. Most of the correlation points aligned with the local along-shore direction have shorter times lags of 10 hours.

\section{Discussion}

\subsection{Bay of Biscay Circulation \\ 4.1.1. Mean Circulation}

The area is characterized by a mean wind veering from eastward to southeastward following the edge of the Azores anticyclone (figure 4) (Isemer and Hasse, 1987). Through the Ekman transport, the mean wind regime would tend to drive a southward to southwestward flow. However, the tidallyfiltered circulation upon the BoBSS is characterized by a mean poleward current. It is interesting to compare the circulation in the BoB to the one over the Mid Atlantic Bight (MAB) for several reasons. Their geometry are both complex with presence of canyons and promontories, they are both located at mid-latitudes, the tide currents are comparable, their stratification are both influenced by freshwater run off and summer heat fluxes. Furthermore, over the MAB, the winds are also perpendicular to the coast (Lentz, 2008) and the mean flow is oriented in the direction leaving the shallow water on the right. Different forcing mechanisms of the mean circulation have been proposed. On one hand, the runoff of freshwater from the river, upwelling dynamics or frontogenesis can force a cross shelf density gradient which contributes to force an along-shore current (Csanady, 1978; Beardsley and Winant, 1979). On the other hand, the shelf circulation is viewed as a 
boundary layer of the open ocean, thus, indirectly driven by the large scale wind stress and heat fluxes which leads to an along-shore pressure gradient (Csanady, 1978). This study indicate that the shelf circulation is most likely a response to the boundary conditions provided by the open ocean and from the coastal circulation that occurs north to the MAB (Chapman and Beardsley, 1989). However Lentz (2008) recently showed that the buoyancy driven flow in equilibrium with the cross shelf density gradient can be described by observations after simply removing the wind driven circulation. Thus, the shelf and upper slope tidally-filtered circulation could be the combination of large scale and local forcing. This likely simultaneous influence of different forcing scales brings the complexity of studying shelf and slope circulations. Our study suggests such complexity by observing two different dynamics on the upper slope and the shelf (figure 7) but the separate influence of both forcing needs to be analysed more carefully to confirm this statement.

The influence of a possible large scale forcing was studied by Pingree and Le Cann (1989). Through numerical experiments, they obtained a circulation on the slope and the northern part of BoB shelf with the same current intensity and orientation as our observations. They explained this vertically averaged poleward circulation on the slope as a result of the combination of the large scale meridional density gradient and the steep slope known as the JEBAR term (Huthnance, 1984). On the northern part of the French continental slope, Pingree and Le Cann (1989) found a current intensity associated with this term comparable to the observed circulation $\left(\sim 5 \mathrm{~cm} \mathrm{~s}^{-1}\right)$. The shelf residual circulation is also poleward but the slope is too smooth to drive a JEBAR current comparable to our observations. The cross shelf 
density gradient, as a consequence of the freshwater runoff from the French rivers (Lazure and Jegou, 1998), can also drive this poleward current but these runoffs strongly depend on the season. In the next section, we will discuss the influence of the wind forcing on the shelf circulation

\subsubsection{Seasonal Circulation}

The seasonal averages show a relatively weak circulation over the upper slope and shelf of the BoB and important seasonal and geographical variabilities (figure 7). In winter, our results present tidally filtered current intensity up to about $\sim 40 \mathrm{~cm} \mathrm{~s}^{-1}$ at the surface of the Penmarc'h section at the 60 $\mathrm{m}$ isobath while, in the $44^{\circ} \mathrm{N}$ section, strong currents occur in summer and autumn with a deep vertical extension. With the exception of these short strong current events in the $44^{\circ} \mathrm{N}$ section on each of instrumented isobaths, the near bottom circulation on the shelf of the BoB presents coherent flows over a large spatial scale. Indeed, current oscillations occur in the late winter and spring seasons with period of a month. For the rest of the year, the currents in the Loire section are correlated either with the $44^{\circ} \mathrm{N}$ section circulation or the Penmarc'h section circulation. It suggests a forcing over the same large spatial scale. The section 4.2 shows the influence of either local or remote winds on this circulation.

The ASPEX data complements the near surface drifter data organized and described by Charria et al. (2011). Looking deeper in the water column, the main seasonal patterns of the surface circulation remain: strong and poleward autumnal currents, a weak shelf circulation in spring and equatorward currents in summer. However, some differences appear in winter where the currents recorded by the ADCP are strong and poleward all over the shelf 
while the lack of information from drifters in the northern part of the BoB led to underestimate the circulation in this area. Because of the low stratification for this season, one can expect weak differences between the surface circulation and the interior flow. Thus, the weak circulation observed by drifters can be explained by less drifter data in winter or the inter-annual variability of the BoB circulation. The winter circulation of the BoBSS is frequently marked by a large scale poleward current off northern Spain (called "Navidad",Pingree (1994)). Garcia-Soto and Pingree (2012) observes in the last three decades (1979-2010) a marked Navidad, all along northern Spain, with an irregular periodicity of 2-6 years (3 years as mean with a standard deviation of $\sim 1$ year). The most recent Navidad event occured at the end of the year 2009 during the ASPEX project. This event most likely influences the strong and barotropic current event in the southern part of the BoBSS during the autumn season.

Our study also highlights the seasonality of the shelf circulation especially the seasonal differences between the summer circulation and the rest of the year. For this season, the mean vertically averaged currents present equatorward currents on the shelf in front of the Loire river and close to the shelf break in the southern part of the BoB (figure 5). Along the $130 \mathrm{~m}$ isobath in Loire and $44^{\circ} \mathrm{N}$ sections, these equatorward currents are increasing from the bottom to the surface. At the $60 \mathrm{~m}$ isobath in front of the Loire river, we observe a marked vertical shear with equatorward currents at the surface and poleward currents at the bottom (figure 6). For this season, the southeastward wind regime can drive the surface intensified equatorward flow but, it does not drive the entire deep circulation in the middle of the continental 
shelf in front of the Loire river. At this location, Vincent and Kurc (1969b) described a structure called "bourrelet froid" (cold pool) which appears after the set up of the seasonal thermocline. This structure tends to drive a surface intensified cyclonic circulation in front of the Loire river (i.e. a poleward flow close to the coast) in the interior of the water column (Charria et al., 2011). Such cyclonic circulation around a cold pool has been observed in the Celtic and Irish sea (Hill, 1993).

Another feature of the summer circulation is the shape of the vertical profiles of the cross-shore velocity component (figure 6). On the shelf, we observe a weak or slightly offshore flow at the bottom while there is a markedly onshore current at the depth of the thermocline. This pattern has been observed along the western American coast (Lentz and Trowbridge, 2001) and over the Mid-Atlantic bight (Lentz, 2008). It fits with the theoretical frame of the Arrested Topographic Wave (ATW) (Csanady, 1978). An along-shore jet with shallow water on the right can drive a downslope current at the bottom in the Ekman layer. By continuity, it lead to an onslope interior flow. However, such patterns observed with an ADCP have to be analyzed carefully because, in a region with enhanced internal waves activities (Pingree and New, 1989), the recorded time series could present strong biases at the thermocline depth. Indeed, an ADCP records the current velocities at fixed depths, thus, the velocities in the layers above and below the thermocline are recorded by the same cell because of the vertical displacement of the thermocline due to the presence of internal waves (Pingree and Le Cann, 1989). From the shelf break to the coast, it may leads to an increase of the observed mean cross-shore velocity in the direction of the phase speed propagation of 
the internal wave because velocity field of internal waves above and below the thermocline are opposed (Phillips, 1977). The observed feature on the vertical profiles of the cross shore currents (figure 6) can be forced either by the ATW mechanism or the bias of an eulerian measurement in an internal waves field.

The internal wave can also influence the circulation at the $450 \mathrm{~m}$ isobath. This isobath is approximatively the depth where internal wave are generated through the interaction with the topography. Internal wave beams are generated at the shelf break and propagate downslope with an angle with the slope depending on the stratification at the generation location. These waves have strong spatial variability and the mean currents associated to these waves can reach $\sim 15 \mathrm{~cm} \mathrm{~s}^{-1}$ on the upper slope near "La Chapelle" bank (Pingree and Le Cann, 1989).

\subsection{Wind Driven circulation}

The correlations between the local winds and the along-shore velocities $(>0.5)$ suggest a strong influence of the wind on the circulation at the $60 \mathrm{~m}$ isobath but our results (figures 8 and 9) suggest two kinds of processes that occurs on the BoBSS. Indeed, the oriented time lagged correlations can be divided into two groups through both direction and time lag criteria.

On one hand, the observed along-shore circulation is well correlated with the along-shore wind and the time lags associated to this dynamics are approximatively twelve hours. The depth-averaged dynamics is primarily forced by the wind stress, along-shelf pressure gradient, and bottom stress (Lentz and Fewings, 2012). A simple frictional and barotropic model (Csanady, 1982) assumes a timescale adjustment to wind forcing defined by $T=H / r$ 
where $\mathrm{T}$ is the time scale adjustment, $\mathrm{H}$ is the water column height and $\mathrm{r}$ the linear bottom friction. In the BoBSS, $\mathrm{r}$ is approximated as $r=C_{d}\left|u_{t i d e}\right|$ with $C_{d}=2.5 \times 10^{-3}$ a friction coefficient and $\left|u_{t i d e}\right|=0.5 \mathrm{~m} \mathrm{~s}^{-1}$ an approximation of the tide current intensity. At the $60 \mathrm{~m}$ isobath and for a linear bottom friction $r=1.3 \times 10^{-3} \mathrm{~m} \mathrm{~s}^{-1}$, we obtain a time scale adjustment of 12 hours. It can be compared to the time lags we observe in the BoBSS.

On the other hand, at $44^{\circ} \mathrm{N}$, the observed along-shore circulation is well correlated with westerlies and the time lags associated to this dynamics are longer than a day. This suggests local along-shore currents forced by remote winds. Such a mechanism implies a longer time lag (Lentz and Fewings, 2012) than for a mechanism where the along-shore currents are driven by the local along-shore winds. Batifoulier et al. (2012) described the circulation in the southern part of the BoB as influenced by the north Spanish coast circulation for summer and autumn. For these seasons, the stratification is strong and the westerlies drive a downwelling circulation. The adjustment of the thermocline to the wind generates baroclinic waves associated with strong current events. In this study, ASPEX data suggest that the southern part of the BoB is influenced by the north Spanish coast circulation during the whole year.

Some correlation points in the Penmarc'h section do not fit with either the frictional model or the remote wind forcing explanation. For spring and summer in this section, the correlation points are aligned with the local alongshore direction with values of 0.4 and time lags about 2-3 days. This indicates a weak driving influence of the along-shore winds on the local circulation. This also strongly suggests that some other mechanisms are able to force the 
main part of the circulation in this section. These other mechanisms may be the driving mechanisms of the $\sim 40 \%$ of the observed circulation which are not explained by the wind forcing in the other sections. The section 5 discusses these driving mechanisms by comparing the circulation observed during the ASPEX project with the well documented area of the Mid Atlantic Bight.

\section{Conclusion}

The circulation in the Bay of Biscay is estimated at 10 locations with observations throughout the water column along three sections from the coast to the upper slope at $60 \mathrm{~m}, 130 \mathrm{~m}$ and $450 \mathrm{~m}$ isobaths. The nearly two year time series are used to describe the mean circulation and its temporal evolution as an eastern ocean boundary circulation. The depth and seasonally averaged currents are poleward throughout the Bay of Biscay except in summer on the shelf in front of the Loire river where the currents can be equatorward. The seasonal variability of these currents is constrained by topography and is weaker on the $130 \mathrm{~m}$ isobath. On the slope, the cross-shore currents are slightly downslope from mid-depth to the near bottom. On the shelf, the near bottom flow is also offshore but in the interior the vertical profiles present a greater variability likely due to the wind, the cross-shore gradient density and likely some bias due to the Eulerian measurement of internal waves activity. The temporal evolution of the circulation presents strong barotropic events observed at $60 \mathrm{~m}$ depth during the summer and autumn seasons in the south of the Bay of Biscay. And in winter, the circulation in the north is characterized by a strong surface intensified variability. 
At the bottom, oscillations of the weekly averaged current can be observed throughout the Bay of Biscay shelf and slope in winter.

The Bay of Biscay shelf and slope circulation may be mainly driven by large scale along-shore pressure gradient, cross-shore buoyancy gradients and the local winds. The data from the ASPEX experiment provides good proxies to separate each of the forcing mechanisms. In our study, a first step is performed estimating the wind driven circulation. At the coast, the wind driven circulation is about $60 \%$ of the total circulation. Locally, in the Penmarc'h and Loire river sections, the variability of the along-shore currents is driven by the along-shore winds with a spin up time around 10 hours. In the $44^{\circ} \mathrm{N}$ section the circulation is likely indirectly driven by the wind blowing along the Spanish coast. Here, the influence of the wind is lagged in time because the currents are possibly remotely forced through coastal trapped wave propagation. The repetition of strong current events from a year to another indicates that the circulation in the French part of the Bay of Biscay shelf and slope seems to be consistent in time despite the changes in the atmospheric forcing and/or the presence or absence of a Navidad current.

Acknowledgment. This work is part of the EPIGRAM project supported by the Agence Nationale de la Recherche (grant ANR-08-BLAN-0330-01) and CNRS/INSU national programme LEFE/IDAO. Special thanks are due to the institutes that provided the data for this study: IFREMER, MétéoFrance. The authors would like to thank the technical staff who worked on the preparation, deployment and the recovery of the instruments. 


\section{Appendix A. Wind stress}

Many formula for the wind stress computation have been proposed (Geernaert, 1987). For this study, we take the wind stress formulation from Smith and Banke (1975):

$$
\begin{gathered}
C s=0.63+0.066\left|\overrightarrow{u_{10}}\right| \\
\vec{\tau}=\rho_{a} C s\left|\overrightarrow{u_{10}}\right| \overrightarrow{u_{10}}
\end{gathered}
$$

$\overrightarrow{u_{10}}$ is the wind vector measured at $10 \mathrm{~m}$ above the sea level, $\rho_{a}$ is the air density $\left(\rho_{a}=1.2 \mathrm{~kg} . \mathrm{m}^{-3}\right)$ and Cs the drag coefficient.

\section{References}

M.A. Al-Zanaidi,B.D. Dore, 1976. Some Aspects of Internal Wave Motions. Pure and Applied Geophysics 3 (14), 403-414.

Batifoulier, F., Lazure, P., Bonneton, P., 2012. Poleward coastal jets induced by westerlies in the Bay of Biscay. Journal of Geophysical Research 117 (C3), 1-19.

Beardsley, R., Winant, C., 1979. On the Mean Circulation in the Mid Atlantic Bight. Journal of Physical Oceanography 9, 612-619.

Björnsson, H., Venegas, S., 1997. A manual for EOF and SVD analyses of climate data. Report. No 97-1, Department of Atmospheric and Oceanic Sciences and Centre for Climate and Global Change Research, McGill University. 52. 
Brown, J., Carrillo, L., Fernand, L., Horsburgh, K., A.E Hill, Young, E., Medler, K., 2003. Observations of the physical structure and seasonal jetlike circulation of the Celtic Sea and St. George's Channel of the Irish Sea. Continental Shelf Research 23 (6), 533-561.

Chapman, D. C., Beardsley, R., 1989. On the Origin of Shelf Water in the Middle Atlantic Bight. Journal of Physical Oceanography 3, 384-391.

Charria, G., Lazure, P., Le Cann, B., Serpette, A., Reverdin, G., Louazel, S., Batifoulier, F., Dumas, F., Pichon, A., Morel, Y., Oct. 2011. Surface layer circulation derived from Lagrangian drifters in the Bay of Biscay. Journal of Marine Systems, in press,doi:10.1016/j.jmarsys2012.09.015

Csanady, G. T., 1978. The Arrested Topographic Wave. Journal of Physical Oceanography 8, 47-62.

Csanady, G. T., 1982. Circulation in the Coastal Ocean, Springer's Edition. Vol. 2687. D. Reidel Publishing Company.

Déqué, M., Dreveton, C., Braun, A., Cariolle, D., 1994. The ARPEGE/IFS atmosphere model: a contribution to the French community climate modelling. Climate Dynamics, 249-266.

Ferrer, L., Fontán, A., Mader, J., Chust, G., González, M., Valencia, V., Uriarte, A., Collins, M., Apr. 2009. Low-salinity plumes in the oceanic region of the Basque Country. Continental Shelf Research 29 (8), 970-984.

Garcia-Soto, C., Pingree, R.D., 2012. Atlantic Multidecadal Oscillation (AMO) and sea surface temperature in the Bay of Biscay and adjacent 
regions. Journal of the Marine Biological Association of the United Kingdom 92(2), 213-234.

Geernaert, G., 1987. On the importance of the drag coefficient in air-sea interactions. Dynamics of Atmospheres and Oceans 11, 19-38.

Godin, G., 1972. The Analysis of Tide, University of Toronto Press,264 pp.

Hill,A.E, 1993. Seasonal Gyre in Shelf Seas. Annales GeophysicaleAtmosphere Hydrospheres and Space 11 (11-12), 1130-1137.

Holloway, G., 1992. Representing Topograhic Stress for Large-Scale Ocean Models. Journal of Physical Oceanography 22 (9), 1033-1046.

Houghton, R., Schlitz, R., Beardsley, R., Butman, B., Chamberlin, J., 1982. Middle Atlantic Bight cold pool: Evolution of the temperature structure during summer 1979. Journal of Physical Oceanography 12 (10), 10191029.

Huthnance, J. M., 1984. Slope Currents and "JEBAR". Journal of Physical Oceanography 14, 795-810.

Isemer, H., Hasse, L., 1987. The Bunker climate atlas of the North Atlantic Ocean. Volume II: Air-sea interactions, springer-v Edition. Vol. II.

Koutsikopoulos, C., Le Cann, B., 1996. Physical processes and hydrological structures related to the Bay of Biscay anchovy. Scienta Marina 60, 9-19.

Lazure, P., Dumas, F., Vrignaud, C., Jul. 2008. Circulation on the Armorican shelf (Bay of Biscay) in autumn. Journal of Marine Systems 72 (1-4), 218237. 
Lazure, P., Jegou, A.M., 1998. 3D modelling of seasonal evolution of Loire and Gironde plumes on Biscay Bay continental shelf. Oceanologica Acta $21(2), 165-177$.

Le Cann, B., 1982. Evolution annuelle de la structure hydrologique du Plateau Continental au sud de la Bretagne. Ph.D. thesis, Université de Bretagne Occidentale.

Le Cann, B., 1988. Dépouillement des données de courants, de températures et d'hydrologie (03/03/198724/04/1987), CIRESOL. Tech. rep., Université de Bretagne Occidentale.

Lentz, S., Trowbridge, J., 2001. A Dynamical Description of Fall and Winter Mean Current Profiles over the Northern California Shelf. Journal of Physical Oceanography 31 (4), 914-931.

Lentz, S. J., Jul. 2008. Seasonal Variations in the Circulation over the Middle Atlantic Bight Continental Shelf. Journal of Physical Oceanography 38 (7), $1486-1500$.

Lentz, S. J., Fewings, M. R., 2012. The Wind- and Wave-Driven Inner-Shelf Circulation. Annual Review of Marine Science 4 (1), 317-343.

Michel, S., A.M. Treguier, Vandermeirsch, F., 2009. Temperature variability in the Bay of Biscay during the past 40 years, from an in situ analysis and a 3D global simulation. Continental Shelf Research 29 (8), 1070-1087.

Phillips, O.M, 1977. The Dynamics of the upper ocean. Cambridge University Press, London. 
Pingree, R., Sinha, B., Griffiths, C.R., 1999. Seasonality of the European slope current (Goban Spur) and ocean margin exchange.. Continental Shelf Research 19 (7), 929-975.

Pingree, R., 1994. Winter Warming in the southern Bay of Biscay and lagrangian eddy kinematics from a deep drogued ARGOS buoy. Journal of the Marine Biological Association of the United Kingdom 74, 107-128.

Pingree, R., 1993. Flow of surface waters to the west of the British Isles and in the Bay of Biscay. Deep Sea Research Part II: Topical Studies in Oceanography 40 (1-2), 369-388.

Pingree, R., Le Cann, B., 1989. Celtic and Armorican slope and shelf residual currents. Progress In Oceanography 23 (4), 303-338.

Pingree, R. D., Le Cann, B., 1990. Structure, strength and seasonality of the slope currents in the Bay of Biscay region. Journal of the Marine Biological Association of the United Kingdom 70 (04), 857-885.

Pingree, R. D., Le Cann, B., 1992. Three anticyclonic Slope Water Oceanic eDDIES (SWODDIES) in the Southern Bay of Biscay in 1990. Deep-Sea Research 39 (718), 1147-1175.

Pingree, R. D., New, A. L., 1989. Downward propagation of internal tidal energy into the Bay of Biscay. Deep Sea Research Part A. Oceanographic Research Papers 36 (5), 735-758.

Pollard, R., Pu, S., 1985. Structure and Circulation of the Upper Atlantic Ocean Northeast of the Azores. Progress In Oceanography 14, 443-462. 
Puillat, I., Lazure, P., Jégou, A., Lampert, L., Miller, P., 2004. Hydrographical variability on the French continental shelf in the Bay of Biscay, during the 1990s. Continental Shelf Research 24 (10), 1143-1163.

Semtner, A., Mintz, Y., 1977. Numerical Simulation of the Gulf Stream and Mid-Ocean Eddies. Journal of Physical Oceanography 7, 208-230.

Smith, S. D., Banke, E. G., 1975. Variation of the sea surface drag coefficient with wind speed. Quarterly Journal of the Royal Meteorological Society 101 (429), 665-673.

Somavilla, R., González-Pola, C., Lavín, a., Rodriguez, C., 2012. Temperature and salinity variability in the south-eastern corner of the Bay of Biscay (NE Atlantic). Journal of Marine Systems,in press,doi:10.1016/j.jmarsys.2012.02.010

Van Aken, H. M., 2002. Surface currents in the Bay of Biscay as observed with drifters between 1995 and 1999. Deep-Sea Research 49, 1071-1086.

Vincent, A., Kurc, G., 1969a. Les Variations de la Situation Thermique dans le Golfe de Gascogne et leur incidence sur l'écologie et la pêche de la sardine en 1968. Trav.Inst.Pêches maritimes 33 (2), 203-212.

Vincent, A., Kurc, G., 1969b. Variations Saisonnières de la Situation Thermique du Golfe de Gascogne en 1967. Rev.Trav.Inst.Pêches maritimes $33(1), 79-96$. 